\section{JURNAL EKONOMI EFEKTIF}

ISSN : $2622-8882$, E-ISSN : 2622-9935

Jurnal Ekonomi Efektif, Vol. 2, No. 4, Juli 2020

@.Prodi Manajemen Fakultas Ekonomi Universitas

Pamulang

\title{
PENGARUH SISTEM REKRUTMEN DAN PENGEMBANGAN KARIR TERHADAP KEPUASAN KERJA PADA PT. KIMIA FARMA DI JAKARTA
}

\author{
Makmur Solahudin \\ Depok Institute, Jawa Barat, Indonesia \\ *makmursolahudin@gmail.com
}

\begin{abstract}
ABSTRAK
Penelitian ini bertujuan untuk mengetahui pengaruh sistem rekrutmen dan pengembangan karir terhadap kepuasan kerja pada PT. Kimia Farma di Jakarta. Metode yang digunakan adalah explanatory research dengan teknik analisis menggunakan analisis statistik dengan pengujian regresi, korelasi, determinasi dan uji hipotesis. Hasil penelitian ini sistem rekrutmen berpengaruh signifikan terhadap kepuasan kerja sebesar 43,8\%, uji hipotesis diperoleh t hitung $>\mathrm{t}$ tabel atau $(6,844>2,000)$. Pengembangan karir berpengaruh signifikan terhadap kepuasan kerja sebesar 39,9\%, uji hipotesis diperoleh $t$ hitung $>\mathrm{t}$ tabel atau $(6,313>2,000)$. Sistem rekrutmen dan pengembangan karir secara simultan berpengaruh signifikan terhadap kepuasan kerja dengan persamaan regresi $\mathrm{Y}=8,752+0,401 \mathrm{X} 1+0,394 \mathrm{X} 2$ dan kontribusi pengaruh sebesar 58,0\%, uji hipotesis diperoleh $\mathrm{F}$ hitung $>\mathrm{F}$ tabel atau $(40,671>2,760)$.
\end{abstract}

\section{Kata Kunci: Sistem Rekrutmen, Pengembangan Karir, Kepuasan Kerja.}

\section{ABSTRACT}

This study aims to determine the effect of the recruitment system and career development on job satisfaction at PT. Kimia Farma in Jakarta. The method used is explanatory research with analysis techniques using statistical analysis with regression testing, correlation, determination and hypothesis testing. The results of this study that the recruitment system has a significant effect on job satisfaction by $43.8 \%$, hypothesis testing is obtained $t$ count $>$ t table or (6,844> 2,000). Career development has a significant effect on job satisfaction by $39.9 \%$, hypothesis testing is obtained $t$ count $>$ t table or $(6.313>2,000)$. The recruitment system and career development simultaneously have a significant effect on job satisfaction with the regression equation $Y=8.752+0.401 X 1+0.394 X 2$ and the contribution of the effect is $58.0 \%$, hypothesis testing obtained $F$ count $>F$ table or (40.671> 2.760).

Keywords: Recruitment System, Career Development, Job Satisfaction. 


\section{PENDAHULUAN}

\section{A. Latar Belakang Masalah}

Kepuasan kerja pada dasarnya merupakan hal yang bersifat individual. Setiap individu memiliki tingkat kepuasan yang berbeda-beda sesuai dengan keinginan dan sistem nilai yang dianutnya. Semakin banyak pekerjaan yang dikerjakan sesuai keinginan dan sistem nilainya pada setiap individu, maka semakin tinggi tingkat kepuasan yang didapat oleh individu tersebut.

Kepuasan kerja mencerminkan perasaan setiap karyawan baik secara positif maupun negatif terhadap pekerjaannya. Menciptakan kepuasan kerja adalah hal yang sangat penting. Adapun masalah kepuasan kerja karyawan yang terjadi pada PT. Kimia Farma Jakarta seperti kurangnya keterampilan dan keahlian para karyawan yang disebabkan proses rekrutmen yang tidak sesuai standar perusahaan, dan terbatasnya promosi bagi karyawan lama. Cara untuk meningkatkan kepuasan kerja adalah dengan rekrutmen. Proses rekrutmen atau penarikan karyawan baru di dalam perusahaan menjadi tanggung jawab departemen personalia. Perusahaan bisa memilih pelamarpelamar yang persyaratannya paling dekat berhubungan dengan kriteria pekerjaan.

Adapun masalah sistem rekrutmen yang terjadi pada PT. Kimia Farma Di Jakarta seperti calon karyawan harus memiliki jenjang pendidikan yang sesuai dengan yang dibutuhkan perusahaan. Masalah lain adalah kurangnya mengadaptasikan teknologi baru yang memudahkan mereka menyelesaikan tugas. Banyak yang kemudian mengabaikan kesempatan berlatih tersebut karena mereka juga tidak melihat manfaat terhadap kepuasan kerja mereka.

Kebutuhan untuk merencanakan karir timbul baik dari kekuatan ekonomis maupun kekuatan sosial, sehingga ada kepuasan yang dirasakan oleh masing-masing karyawan. Adapun masalah pengembangan karir yang terjadi pada PT. Kimia Farma Di Jakarta seperti waktu pelatihan dan pendidikan relatif singkat, pelatihan dan pendidikan yang diberikan tidak sesuai dengan keahlian dan keterampilan para calon karyawan sehingga mereka tidak mengembangkan potensi yang ada pada diri mereka.

Berdasarkan pemaparan di atas, maka penulis mengambil judul penelitian "Pengaruh Sistem Rekrutmen dan Pengembangan Karir Terhadap Kepuasan Kerja Karyawan Pada PT. Kimia Farma di Jakarta".

\section{B. Rumusan Masalah}

1. Adakah pengaruh antara sistem rekrutmen terhadap kepuasan kerja pada PT. Kimia Farma di Jakarta?

2. Adakah pengaruh antara pengembangan karir terhadap kepuasan kerja pada PT. Kimia Farma di Jakarta?

3. Adakah pengaruh secara simultan antara sistem rekrutmen dan pengembangan karir terhadap kepuasan kerja pada PT. Kimia Farma di Jakarta?

\section{Tujuan Penelitian}

1. Untuk mengetahui pengaruh antara sistem rekrutmen terhadap kepuasan kerja pada PT. Kimia Farma di Jakarta.

2. Untuk mengetahui pengaruh antara pengembangan karir terhadap kepuasan kerja pada PT. Kimia Farma di Jakarta.

3. Untuk mengetahui pengaruh secara simultan antara sistem rekrutmen dan pengembangan karir terhadap kepuasan kerja pada PT. Kimia Farma di Jakarta. 


\section{TINJAUAN PUSTAKA}

\section{Sistem rekrutmen}

Menurut Sirait (2006), rekrutmen atau penarikan calon karyawan merupakan serangkaian kegiatan yang dilakukan secara terencana, guna memperoleh calon-calon karyawan yang memenuhi syarat-syarat yang dituntut oleh suatu jabatan tertentu yang dibutuhkan oleh suatu perusahaan. Sedangkan rekrutmen menurut Hasibuan (2009), adalah usaha mencari dan mempengaruhi tenaga kerja, agar mau melamar lowongan pekerjaan yang ada dalam suatu perusahaan. Sedangkan menurut Handoko (2008), rekrutmen merupakan proses pencarian dan "pemikatan" para calon karyawan (pelamar) yang mampu untuk melamar sebagai karyawan.

\section{Pengembangan karir}

Menurut Henry Simamora (2006), karir merupakan urutan aktivitas- aktivitas yang berhubungan dengan pekerjaan dan perilaku, nilai-nilai dan aspirasi seseorang selama rentang hidup orang tersebut. Menurut Moekijat (2008), karir dapat diartikan: Kemajuan seseorang dalam suatu upaya pekerjaan yang diperolehnya selama bekerja, Kemajuan seseorang dalam bidang pekerjaan selama bertahun-tahun bekerja. Perkembangan kemajuan seseorang dalam suatu lapangan pekerjaan selama masa aktif riwayat hidupnya. Lain halnya menurut Veithal Rivai (2009), menyatakan bahwa karir terdiri dari semua pekerjaan yang ada selama orang bekerja, atau dapat dikatakan bahwa karir adalah seluruh jabatan yang diduduki seorang dalam kehidupan kerjanya

\section{Kepuasan kerja}

Menurut Veithzal Rivai (2009), kepuasan kerja (job satisfaction) merujuk pada sikap umum seseorang individu terhadap pekerjaannya. Seseorang dengan tingkat kepuasan kerja tinggi menunjukkan sikap yang positif terhadap pekerjaannya, sebaliknya seseorang tidak puas dengan pekerjaannya menunjukkan sikap yang negatif terhadap pekerjaannya. Sedangkan menurut S.P Malayu Hasibuan (2006), kepuasan kerja adalah sikap emosional yang menyenangkan dan mencintai pekerjaannya. Sikap ini tercermin dari moral kerja, kedisiplinan dan prestasi kerja. Kepuasan kerja dinikmati dalam pekerjaan, luar pekerjaan, dan kombinasi dalam dan diluar pekerjaan

\section{METODE PENELITIAN}

\section{Populasi}

Populasi dalam penelitian ini berjumlah 62 responden PT. Kimia Farma di Jakarta

\section{Sampel}

Sampel dalam penelitian ini berjumlah 62 responden.

\section{Jenis Penelitian}

Jenis penelitian yang dipakai adalah asosiatif, dimana tujuannya adalah untuk mengetahui pengaruh antara variabel bebas terhadap variabel terikat baik parsial maupun simultan

4. Metode Analisis Data

Dalam menganalisis data digunakan uji instrumen, uji asumsi klasik, regresi, koefisien determinasi dan uji hipotesis.

IV. HASIL PENELITIAN

1. Analisis Deskriptif 
Pada pengujian ini digunakan untuk mengetahui skor minimum dan maksimum, mean score dan standar deviasi dari masing-masing variabel. Adapun hasilnya sebagai berikut:

Tabel Hasil Analisis Descriptive Statistics

\section{Descriptive Statistics}

\begin{tabular}{l|r|r|r|r|r} 
& N & Minimum & Maximum & Mean & \multicolumn{1}{c}{ Std. Deviation } \\
\hline Sistem rekrutmen (X1) & 62 & 31 & 48 & 37.34 & 4.227 \\
\hline Pengembangan karir (X2) & 62 & 28 & 45 & 37.13 & 3.800 \\
\hline Kepuasan kerja (Y) & 62 & 31 & 47 & 38.34 & 3.566 \\
\hline Valid N (listwise) & 62 & & & & \\
\hline
\end{tabular}

Sistem rekrutmen diperoleh varians minimum sebesar 31 dan varians maximum 48 dengan mean score sebesar 3,73 dengan standar deviasi 4,227.

Pengembangan karir diperoleh varians minimum sebesar 28 dan varians maximum 45 dengan mean score sebesar 3,71 dengan standar deviasi 3,800.

Kepuasan kerja diperoleh varians minimum sebesar 31 dan varians maximum 47 dengan mean score sebesar 3,83 dengan standar deviasi 3,566.

\section{Analisis Kuantitatif.}

Pada analisis ini dimaksudkan untuk mengetahui pengaruh variabel independen terhadap variabel dependen. Adapun hasil pengujian sebagai berikut:

\section{a. Analisis Regresi Linier Berganda}

Uji regresi ini dimaksudkan untuk mengetahui perubahan variabel dependen jika variabel independen mengalami perubahan. Adapun hasil pengujiannya sebagai berikut:

Tabel Hasil Pengujian Regresi Linier Berganda

\begin{tabular}{|c|c|c|c|c|c|c|}
\hline & & $\mathrm{Cc}$ & fficients ${ }^{a}$ & & & \\
\hline & & $\begin{array}{r}\text { Unsta } \\
\text { Coe }\end{array}$ & $\begin{array}{l}\text { dardized } \\
\text { icients }\end{array}$ & $\begin{array}{l}\text { Standardized } \\
\text { Coefficients }\end{array}$ & & \\
\hline & del & $\mathrm{B}$ & Std. Error & Beta & $\mathrm{t}$ & Sig. \\
\hline & (Constant) & 8.752 & 3.317 & & 2.638 & .011 \\
\hline & Sistem rekrutmen (X1) & .401 & .080 & .475 & 5.033 & .000 \\
\hline & $\begin{array}{l}\text { Pengembangan karir } \\
(\mathrm{X} 2)\end{array}$ & .394 & .089 & .420 & 4.451 & .000 \\
\hline
\end{tabular}

Berdasarkan hasil pengujian pada tabel di atas, diperoleh persamaan regresi $\mathrm{Y}=$ $8,752+0,401 X 1+0,394 X 2$. Dari persamaan tersebut dijelaskan sebagai berikut:

1) Konstanta sebesar 8,752 diartikan jika sistem rekrutmen dan pengembangan karir tidak ada, maka telah terdapat nilai kepuasan kerja sebesar 8,752 point.

2) Koefisien regresi sistem rekrutmen sebesar 0,401, angka ini positif artinya setiap ada peningkatan sistem rekrutmen sebesar 0,401 maka kepuasan kerja juga akan mengalami peningkatan sebesar 0,401 point.

3) Koefisien regresi pengembangan karir sebesar 0,394, angka ini positif artinya setiap ada peningkatan pengembangan karir sebesar 0,394 maka kepuasan kerja juga akan mengalami peningkatan sebesar 0,394 point.

\section{b. Analisis Koefisien Korelasi}

Analisis koefisien korelasi dimaksudkan untuk mengetahui tingkt kekuatan hubungan dari variabel independen terhadap variabel dependen baik secara parsial maupun simultan. Adapun hasil pengujian sebagai berikut:

Tabel Hasil Pengujian Koefisien Korelasi Sistem rekrutmen Terhadap Kepuasan kerja. 


\begin{tabular}{llrr} 
& \multicolumn{2}{c}{ Correlations $^{\mathbf{b}}$} & \\
& & $\begin{array}{c}\text { Sistem } \\
\text { rekrutmen (X1) }\end{array}$ & Kepuasan kerja (Y) \\
\hline Sistem rekrutmen (X1) & Pearson Correlation & 1 & $.662^{* *}$ \\
\cline { 2 - 4 } & Sig. (2-tailed) & .000 \\
\hline Kepuasan kerja (Y) & Pearson Correlation & $.662^{* *}$ & 1 \\
\cline { 2 - 4 } & Sig. (2-tailed) & .000 & \\
\hline
\end{tabular}

Berdasarkan hasil pengujian diperoleh nilai korelasi sebesar 0,662 artinya sistem rekrutmen memiliki hubungan yang kuat terhadap kepuasan kerja.

Tabel Hasil Pengujian Koefisien Korelasi Pengembangan karir Terhadap Kepuasan kerja.

\begin{tabular}{|c|c|c|c|}
\hline \multicolumn{4}{|c|}{ Correlations $^{b}$} \\
\hline & & $\begin{array}{l}\text { Pengembangan } \\
\text { karir }(\mathrm{X} 2)\end{array}$ & Kepuasan kerja $(\mathrm{Y})$ \\
\hline \multirow{2}{*}{$\begin{array}{l}\text { Pengembangan karir } \\
\text { (X2) }\end{array}$} & Pearson Correlation & 1 & $.632^{\star *}$ \\
\hline & Sig. (2-tailed) & & .000 \\
\hline \multirow[t]{2}{*}{ Kepuasan kerja (Y) } & Pearson Correlation & $.632^{* *}$ & 1 \\
\hline & Sig. (2-tailed) & .000 & \\
\hline
\end{tabular}

Berdasarkan hasil pengujian diperoleh nilai korelasi sebesar 0,632 artinya pengembangan karir memiliki hubungan yang kuat terhadap kepuasan kerja.

Tabel Hasil Pengujian Koefisien Korelasi Sistem rekrutmen dan Pengembangan karir secara simultan Terhadap Kepuasan kerja.

\section{Model Summary}

\begin{tabular}{|c|c|c|c|c|}
\hline \multicolumn{5}{|c|}{ summary } \\
\hline Model & $\mathrm{R}$ & R Square & $\begin{array}{l}\text { Adjusted R } \\
\text { Square }\end{array}$ & $\begin{array}{l}\text { Std. Error of the } \\
\text { Estimate }\end{array}$ \\
\hline 1 & $.761^{a}$ & .580 & .565 & 2.351 \\
\hline
\end{tabular}

a. Predictors: (Constant), Pengembangan karir (X2), Sistem rekrutmen (X1)

Berdasarkan hasil pengujian diperoleh nilai korelasi sebesar 0,761 artinya sistem rekrutmen dan pengembangan karir secara simultan memiliki hubungan yang kuat terhadap kepuasan kerja.

\section{c. Analisis Koefisien Determinasi}

Analisis koefisien determinasi dimaksudkan untuk mengetahui besarnya persentase pengaruh dari variabel independen terhadap variabel dependen baik secara parsial maupun simultan. Adapun hasil pengujian sebagai berikut:

Tabel Hasil Pengujian Koefisien Determinasi Sistem rekrutmen Terhadap Kepuasan kerja.

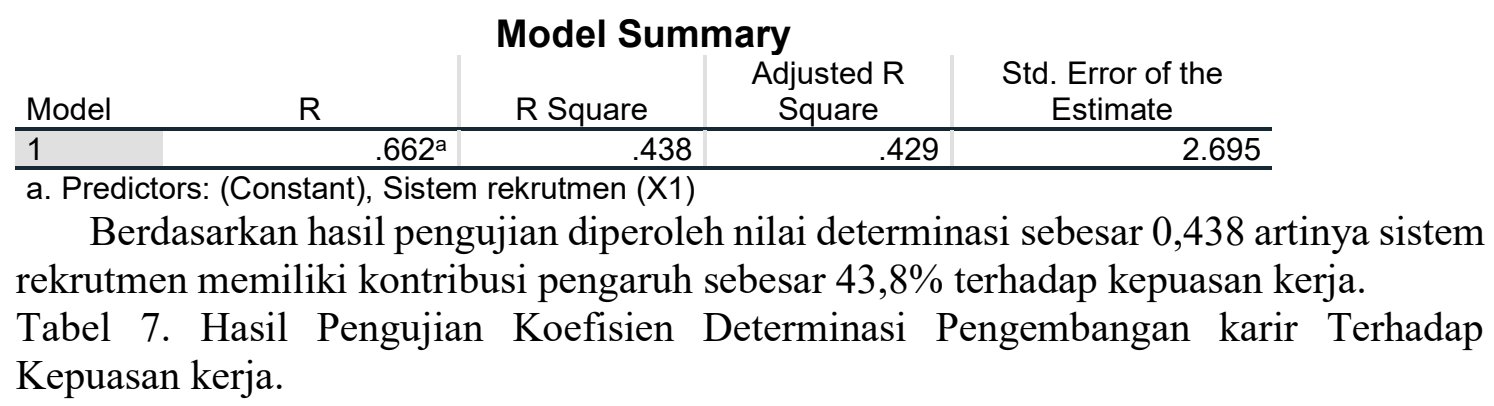




\begin{tabular}{|c|c|c|c|c|}
\hline \multicolumn{5}{|c|}{ Model Summary } \\
\hline Model & $\mathrm{R}$ & R Square & $\begin{array}{l}\text { Adjusted R } \\
\text { Square }\end{array}$ & $\begin{array}{l}\text { Std. Error of the } \\
\text { Estimate }\end{array}$ \\
\hline 1 & $.632^{a}$ & .399 & .389 & 2.788 \\
\hline
\end{tabular}

Berdasarkan hasil pengujian diperoleh nilai determinasi sebesar 0,399 artinya pengembangan karir memiliki kontribusi pengaruh sebesar 39,9\% terhadap kepuasan kerja.

Tabel Hasil Pengujian Koefisien Determinasi Sistem rekrutmen dan Pengembangan karir Terhadap Kepuasan kerja.

\section{Model Summary}

\begin{tabular}{lrr|rr|r} 
Model & $\mathrm{R}$ & \multicolumn{2}{c|}{$\begin{array}{c}\text { Adjusted R } \\
\text { Square }\end{array}$} & \multicolumn{2}{c}{$\begin{array}{c}\text { Std. Error of the } \\
\text { Estimate }\end{array}$} \\
\hline 1 & & R Square & .560 & .565 & 2.351 \\
\hline
\end{tabular}

a. Predictors: (Constant), Pengembangan karir (X2), Sistem rekrutmen (X1)

Berdasarkan hasil pengujian diperoleh nilai determinasi sebesar 0,580 artinya sistem rekrutmen dan pengembangan karir secara simultan memiliki kontribusi pengaruh sebesar 58,0\% terhadap kepuasan kerja, sedangkan sisanya sebesar $42,0 \%$ dipengaruhi faktor lain.

\section{d. Uji Hipotesis}

\section{Uji hipotesis Parsial (Uji t)}

Pengujian hipotesis dengan uji t digunakan untuk mengetahui hipotesis parsial mana yang diterima.

Hipotesis pertama: Terdapat pengaruh yang signifikan antara sistem rekrutmen terhadap kepuasan kerja.

Tabel Hasil Uji Hipotesis Sistem rekrutmen Terhadap Kepuasan kerja.

\begin{tabular}{|c|c|c|c|c|c|c|}
\hline & & & fficients ${ }^{a}$ & & & \\
\hline & & $\begin{array}{r}\text { Unsta } \\
\text { Coe }\end{array}$ & $\begin{array}{l}\text { dardized } \\
\text { icients }\end{array}$ & $\begin{array}{l}\text { Standardized } \\
\text { Coefficients }\end{array}$ & & \\
\hline & & $\mathrm{B}$ & Std. Error & Beta & $\mathrm{t}$ & Sig. \\
\hline 1 & (Constant) & 17.479 & 3.067 & & 5.699 & .000 \\
\hline & Sistem rekrutmen $(\mathrm{X} 1)$ & .559 & .082 & .662 & 6.844 & .000 \\
\hline
\end{tabular}

a. Dependent Variable: Kepuasan kerja $(\mathrm{Y})$

Berdasarkan hasil pengujian pada tabel di atas, diperoleh nilai $\mathrm{t}$ hitung $>\mathrm{t}$ tabel atau $(6,844>2,000)$, dengan demikian hipotesis pertama yang diajukan bahwa terdapat pengaruh yang signifikan atara sistem rekrutmen terhadap kepuasan kerja diterima.

Tabel Hasil Uji Hipotesis Pengembangan karir Terhadap Kepuasan kerja.

\begin{tabular}{|c|c|c|c|c|c|c|}
\hline & & $\mathrm{Co}$ & fficients ${ }^{a}$ & & & \\
\hline & & $\begin{array}{r}\text { Unstar } \\
\text { Coe }\end{array}$ & $\begin{array}{l}\text { dardized } \\
\text { icients }\end{array}$ & $\begin{array}{l}\text { Standardized } \\
\text { Coefficients }\end{array}$ & & \\
\hline & & $B$ & Std. Error & Beta & $t$ & Sig. \\
\hline 1 & (Constant) & 16.326 & 3.505 & & 4.658 & .000 \\
\hline & $\begin{array}{l}\text { Pengembangan karir } \\
\text { (X2) }\end{array}$ & .593 & .094 & .632 & 6.313 & .000 \\
\hline
\end{tabular}

Berdasarkan hasil pengujian pada tabel di atas, diperoleh nilai $t$ hitung $>\mathrm{t}$ tabel 
atau $(6,313>2,000)$, dengan demikian hipotesis kedua yang diajukan bahwa terdapat pengaruh yang signifikan atara pengembangan karir terhadap kepuasan kerja diterima.

\section{Uji Hipotesis Simultan (Uji F)}

Pengujian hipotesis dengan uji $\mathrm{F}$ digunakan untuk mengetahui hipotesis simultan yang mana yang diterima.

Hipotesis ketiga Terdapat pengaruh yang signifikan antara sistem rekrutmen dan pengembangan karir terhadap kepuasan kerja.

Tabel Hasil Uji Hipotesis Sistem rekrutmen dan Pengembangan karir Terhadap Kepuasan kerja.

\begin{tabular}{|c|c|c|c|c|c|c|}
\hline \multicolumn{7}{|c|}{ ANOVA $^{a}$} \\
\hline Model & & Sum of Squares & df & Mean Square & $F$ & Sig. \\
\hline \multirow[t]{3}{*}{1} & Regression & 449.701 & 2 & 224.851 & 40.671 & $.000^{\mathrm{b}}$ \\
\hline & Residual & 326.186 & 59 & 5.529 & & \\
\hline & Total & 775.887 & 61 & & & \\
\hline
\end{tabular}

Berdasarkan hasil pengujian pada tabel di atas, diperoleh nilai $\mathrm{F}$ hitung $>\mathrm{F}$ tabel atau $(40,671>2,760)$, dengan demikian hipotesis ketiga yang diajukan bahwa terdapat pengaruh yang signifikan atara sistem rekrutmen dan pengembangan karir terhadap kepuasan kerja diterima.

\section{Pembahasan Hasil Penelitian}

\section{Pengaruh Sistem rekrutmen Terhadap Kepuasan kerja}

Sistem rekrutmen berpengaruh signifikan terhadap kepuasan kerja dengan korelasi sebesar 0,662 atau memiliki hubungan yang kuat dengan kontribusi pengaruh sebesar $43,8 \%$. Pengujian hipotesis diperoleh nilai $t$ hitung $>t$ tabel atau $(6,844>2,000)$. Dengan demikian hipotesis pertama yang diajukan bahwa terdapat berpengaruh signifikan antara sistem rekrutmen terhadap kepuasan kerja diterima.

\section{Pengaruh Pengembangan karir Terhadap Kepuasan kerja}

Pengembangan karir berpengaruh signifikan terhadap kepuasan kerja dengan korelasi sebesar 0,632 atau memiliki hubungan yang kuat dengan kontribusi pengaruh sebesar $39,9 \%$. Pengujian hipotesis diperoleh nilai t hitung $>t$ tabel atau $(6,313>2,000)$. Dengan demikian hipotesis kedua yang diajukan bahwa terdapat berpengaruh signifikan antara pengembangan karir terhadap kepuasan kerja diterima.

\section{Pengaruh Sistem rekrutmen dan Pengembangan karir Terhadap Kepuasan kerja}

Sistem rekrutmen dan pengembangan karir berpengaruh signifikan terhadap kepuasan kerja dengan diperoleh persamaan regresi $\mathrm{Y}=8,752+0,401 \mathrm{X} 1+0,394 \mathrm{X} 2$, nilai korelasi sebesar 0,761 atau memiliki hubungan yang kuat dengan kontribusi pengaruh sebesar $58,0 \%$ sedangkan sisanya sebesar $42,0 \%$ dipengaruhi faktor lain. Pengujian hipotesis diperoleh nilai $\mathrm{F}$ hitung $>\mathrm{F}$ tabel atau $(40,671>2,760)$. Dengan demikian hipotesis ketiga yang diajukan bahwa terdapat berpengaruh signifikan antara sistem rekrutmen dan pengembangan karir terhadap kepuasan kerja diterima.

\section{KESIMPULAN DAN SARAN}

1. Kesimpulan

a. Sistem rekrutmen berpengaruh signifikan terhadap kepuasan kerja dengan kontribusi pengaruh sebesar 43,8\%. Uji hipotesis diperoleh nilai t hitung $>\mathrm{t}$ tabel atau $(6,844>$ 
2,000).

b. Pengembangan karir berpengaruh signifikan terhadap kepuasan kerja dengan kontribusi pengaruh sebesar $39,9 \%$. Uji hipotesis diperoleh nilai $t$ hitung $>\mathrm{t}$ tabel atau $(6,313>$ 2,000).

c. Sistem rekrutmen dan pengembangan karir berpengaruh signifikan terhadap kepuasan kerja dengan kontribusi pengaruh sebesar 58,0\% sedangkan sisanya sebesar $42,0 \%$ dipengaruhi faktor lain. Uji hipotesis diperoleh nilai $\mathrm{F}$ hitung $>\mathrm{F}$ tabel atau $(40,671>$ $2,760)$.

\section{Saran}

a. Pihak manajemen perusahaan dapat meningkatkan 8actor rekerutmen mereka, karena dengan ditingkatkannya 8actor rekrutmen maka kepuasan kerja juga akan meningkat.

b. Peranan pengembangan karir juga memiliki pengaruh yang positif dan signifikan terhadap kepuasan kerja karyawan, oleh karena itu perusahaan juga harus menerapkan kebijakan pengembangan karir yang tepat, karena dengan menerapkan kebijakan pemngembangan karir yang tepat maka kepuasan kerja karyawan juga akan meningkat. Bagi peneliti lain di sarankan untuk melakukan

c. pengembangan-pengembangan terhadap judul yang di teliti agar mampu mengetahui 8actor-faktor yang mempengaruhi kepuasan kerja.

\section{DAFTAR PUSTAKA}

Agustini, Fauziah, 2011. Manajemen Sumber Daya Manusia Lanjutan, Medan Madenatera.

Anwar Prabu Mangkunegara, (2011). Manajemen Sumber Daya Manusia Perusahaan. Edisi Kesepuluh, Bandung: PT. Remaja Rosda Karya.

Deden Sutisna, (2011). Manajemen Sumber Daya Manusia, Edisi Kedua, Bandung: BP USB. Handoko T. Hani. 2008. Manajemen Personalia dan Sumber Daya Manusia. Penerbit BPFE. Yogyakarta.

Hariandja, Marihot Tua Effendi. 2007. Manajemen Sumber Daya Manusia, Pengadaan, Pengembangan, Pengkompensasian, dan Peningkatan Produktivitas Karyawan, Jakarta: PT. GrasindoWahyudi, Bambang, 2007, Manajemen Sumber Daya Manusia, Sulita, Bandung.

Hasibuan, Malayu S.P. 2009. Manajemen Sumber Daya Manusia, Jakarta : PT Bumi Aksara. Marwansyah. 2012. Manajemen Sumber Daya Manusia. Alfabeta : Bandung. [10] Rachman, Taufik, 2009. Manajemen Sumber Daya Manusia. Ciptapustaka Media Perintis : Bandung.

Ilham, D. (2014). Implementasi Nilai-Nilai Keagamaan pada Mata Pelajaran Umum dalam

Upaya Peningkatan Akhlak Peserta Didik di MAN Malili Kabupaten Luwu

Timur (Doctoral dissertation, STAIN/IAIN Palopo).

Ilham, D. (2019). Implementing Local Wisdom Values in Bride and Groom Course at KUA

Bara SubDistrict, Palopo City. Jurnal Konsepsi, 8(1), 1-9.

Ilham, D. (2019). Menggagas Pendidikan Nilai dalam Sistem Pendidikan

Nasional. Didaktika: Jurnal Kependidikan, 8(3), 109-122.

Moekijat. 2008. Analisis Jabatan, Bandung : Bandar Maju.

Munandar, A, S. 2005, Peran Budaya Organisasi dalam Peningkatan untuk Kerja Perusahaan.Bagian Psikologi Industri dan Organisasi Fakultas UL Jakarta.

Oos Khosiah (2010), Pengaruh sistem rekrutmen dan pengembangan karir terhadap kinerja karyawan pada PT. Dirgantara Indonesia Bandung, Universitas Komputer Indonesia.

Sastrohadiwiryo, siswanto B. 2005. Manajemen Tenaga Kerja Indonesia Pendekata 
Administratif dan Operasional, Edisi Ketiga, Jakarta : Bumi Aksara

Septyaningsih Ekayadi (2009) dengan Judul Pengaruh Motivasi dan Pengembangan Karier

Terhadap Kepuasan Kerja Karyawan Pada PT. Rimbajatiraya Citrakarya.

Siagian, Sondang P. 2006. Manajemen Sumber Daya Manusia, Penerbit Bumi Aksara, Jakarta.

Simamora, Henry, 2006, Manajemen Sumber Daya Manusia, STIE YKPN, Edisi Ketiga, Yogyakarta..

Sirait, Justine. 2006. Memahami Aspek-Aspek Pengelolaan Sumber Daya Manusia Dalam Organisasi. Garasindo: Jakarta.

Sunarsi, D. (2019). Seminar Sumber Daya Manusia. Tangerang Selatan: Unpam Press

Sunarsi, D., \& Kusjono, G. (2019). Pengaruh Lingkungan Kerja Non Fisik, Konflik Dan Turn Over Intention Terhadap Produktivitas Kerja Karyawan Pada CV. Usaha Mandiri Jakarta Selatan. Jurnal Ekonomi Efektif, 1(3).

Suprihatin, L., \& Gunarda, G. (2019). Pengaruh Disiplin Dan Kompensasi Terhadap Kinerja Pegawai Di Pusat Pendidikan Dan Pelatihan Pegawai Kementerian Pendidikan Dan Kebudayaan. JENIUS (Jurnal Ilmiah Manajemen Sumber Daya Manusia), 2(2), 278289.

Sutrisno, Edy. 2009. Manajemen Sumber Daya Manusia, Jakarta, PT Prenada Media Group.

Tri Oktavia Manik (2011), Pengaruh Pemberian insentif dan Pengembangan Karir Terhadap Kepuasan Kerja Pegawai Pada PT. XL.AXIATA West Region, Universitas Negeri Medan.

Veithzal, Rivai. 2009. "Manajemen Sumber Daya Manusia Untuk

Winata, H. (2019). Hubungan Motivasi Terhadap Kinerja Karyawan Pada Bank Pembangunan Daerah Jawa Barat Dan Banten Tbk.(Bank Bjb) Cabang Bsd-Tangerang Selatan. JENIUS (Jurnal Ilmiah Manajemen Sumber Daya Manusia), 2(2), 212-223. 